INOBIS: Jurnal Inovasi Bisnis dan Manajemen Indonesia

Volume 2, Nomor 1, Desember 2018

Kristina Sedyastuti

\title{
Analisis Pemberdayaan UMKM dan Peningkatan Daya Saing Dalam Kancah Pasar Global
}

\author{
Kristina Sedyastuti \\ Universitas Bina Darma \\ kristinasedyastuti@yahoo.com
}

\begin{abstract}
Abstrak
Pemberdayaan UMKM (Usaha Mikro Kecil Menengah) di tengah arus globalisasi dan tingginya persaingan membuat UMKM harus mampu mengadapai tantangan global, seperti meningkatkan inovasi produk dan jasa, pengembangan sumber daya manusia dan teknologi, serta perluasan area pemasaran. Hal ini perlu dilakukan untuk menambah nilai jual UMKM itu sendiri, utamanya agar dapat bersaing dengan produk-produk asing yang kian membanjiri sentra industri dan manufaktur di Indonesia, mengingat UMKM adalah sektor ekonomi yang mampu menyerap tenaga kerja terbesar di Indonesia (Sudaryanto, 2011). Belum kokohnya fundamental perekonomian Indonesia mendorong pemerintah untuk membangun struktur ekonomi dengan mempertimbangkan keberadaan UMKM. Sektor ini telah terbukti memberikan lapangan kerja dan memberikan kesempatan bagi UMKM untuk berkembang di masyarakat. Keberadaan UMKM tidak dapat diragukan karena terbukti mampu bertahan dan menjadi penggerak ekonomi, terutama setelah krisis ekonomi. Di sisi lain, UKM juga menghadapi banyak masalah, yaitu keterbatasan modal kerja, sumber daya manusia yang rendah, dan kurang cakapnya penguasaan ilmu pengetahuan dan teknologi. Metode Penelitian ini menggunakan pendekatan eksploratif deskriptif dengan menganalisis strategi pemberdayaan UMKM dalam menghadapai pasar Global. Karya ilmiah ini juga dikembangkan dengan menggunakan pendekatan kajian literatur atau studi putaka. Pendekatan teori/konsep dilakukan dengan merujuk dari beberapa sumber, seperti buku dan jurnal ilmiah. Semua uraian gagasan yang ada digabungkan dalam satu susunan kerangka pemikiran. Kendala lain yang dihadapi oleh UMKM adalah hubungan dengan prospek bisnis yang kurang jelas dan perencanaan visi misi yang belum stabil. Pemberian informasi dan jaringan pasar, kemudahan akses pendanaan dan pendampingan serta peningkatan kapasitas teknologi informasi merupakan beberapa strategi peningkatan daya saing UMKM Indonesia, yang tak kalah pentingnya adalah jiwa kewirausahaan yang tak pantang menyerah. Oleh karena itu diperlukan sinergi semua pihak terutama antara pelaku usaha, pemerintah dan lembaga keuangan mikro.
\end{abstract}

Kata kunci : UMKM, strategi, pemberdayaan, daya saing

\section{Pendahuluan}

Belum kokohnya fundamental perekonomian Indonesia saat ini, mendorong pemerintah untuk terus memberdayakan Usaha Mikro Kecil dan Menengah (UMKM), yang selanjutnya penulis akan mennggunakan singkatan ini. Sektor ini mampu menyerap tenaga kerja cukup besar dan memberi peluang bagi UMKM untuk berkembang dan bersaing dengan perusahaan yang lebih cenderung menggunakan modal besar (capital intensive). Eksistensi UMKM memang tidak dapat diragukan lagi karena terbukti mampu bertahan dan menjadi roda penggerak ekonomi, terutama pasca krisis ekonomi. Disisi lain, UMKM juga menghadapi 
INOBIS: Jurnal Inovasi Bisnis dan Manajemen Indonesia

Volume 2, Nomor 1, Desember 2018

Kristina Sedyastuti

banyak sekali permasalahan, yaitu terbatasnya modal kerja, Sumber Daya Manusia yang rendah, dan minimnya penguasaan ilmu pengetahuan serta teknologi (Sudaryanto dan Hanim, 2002). Kendala lain yang dihadapi UMKM adalah keterkaitan dengan prospek usaha yang kurang jelas serta perencanaan, visi dan misi yang belum mantap. Hal ini terjadi karena umumnya UMKM bersifat income gathering yaitu menaikkan pendapatan, dengan ciri-ciri sebagai berikut: merupakan usaha milik keluarga, menggunakan teknologi yang masih relatif sederhana, kurang memiliki akses permodalan (bankable), dan tidak ada pemisahan modal usaha dengan kebutuhan pribadi.

Pemberdayaan UMKM di tengah arus globalisasi dan tingginya persaingan membuat UMKM harus mampu mengadapai tantangan global, seperti meningkatkan inovasi produk dan jasa, pengembangan sumber daya manusia dan teknologi, serta perluasan area pemasaran. Hal ini perlu dilakukan untuk menambah nilai jual UMKM itu sendiri, utamanya agar dapat bersaing dengan produk-produk asing yang kian membanjiri sentra industri dan manufaktur di Indonesia, mengingat UMKM adalah sektor ekonomi yang mampu menyerap tenaga kerja terbesar di Indonesia (Sudaryanto, 2011). Pada tahun 2011 UMKM mampu berandil besar terhadap penerimaan negara dengan menyumbang 61,9 persen pemasukan produk domestik bruto (PDB) melalui pembayaran pajak, yang diuraikan sebagai berikut : sektor usaha mikro menyumbang 36,28 persen PDB, sektor usaha kecil 10,9 persen, dan sektor usaha menengah 14,7 persen melalui pembayaran pajak. Sementara itu, sektor usaha besar hanya menyumbang 38,1 persen PDB melalui pembayaran pajak (BPS, 2011). Sebagian besar (hampir 99 persen), UMKM di Indonesia adalah usaha mikro di sektor informal dan pada umumnya menggunakan bahan baku lokal dengan pasar lokal. Itulah sebabnya tidak terpengaruh secara langsung oleh krisis global. Laporan World Economic Forum (WEF) 2010 menempatkan pasar Indonesia pada ranking ke-15. Hal ini menunjukkan bahwa Indonesia sebagai pasar yang potensial bagi negara lain. Potensi ini yang belum dimanfaatkan oleh UMKM secara maksimal. Perkembangan UMKM di Indonesia masih dihadapkan pada berbagai persoalan sehingga menyebabkan lemahnya daya saing terhadap produk impor.

Persoalan utama yang dihadapi UMKM, antara lain keterbatasan infrastruktur dan akses pemerintah terkait dengan perizinan dan birokrasi serta tingginya tingkat pungutan. Dengan segala persoalan yang ada, potensi UMKM yang besar itu menjadi terhambat. Meskipun UMKM dikatakan mampu bertahan dari adanya krisis global namun pada kenyataannya permasalahan-permasalahan yang dihadapi sangat banyak dan lebih berat. Hal itu dikarenakan selain dipengaruhi secara tidak langsung krisis global tadi, UMKM harus pula menghadapi persoalan domestik yang tidak kunjung terselesaikan seperti masalah upah buruh, ketenaga kerjaan dan pungutan liar, korupsi dan lain-lain. Permasalahan lain yang dihadapi UMKM, yaitu adanya liberalisasi perdagangan, seperti pemberlakuan ASEAN- China Free Trade Area (ACFTA) yang secara efektif telah berlaku tahun 2010. Disisi lain, Pemerintah telah menyepakati perjanjian kerja sama ACFTA ataupun perjanjian lainnya, namun tanpa mempertimbangkan terlebih dahulu kesiapan UMKM agar mampu bersaing. Sebagai contoh kesiapan kualitas produk, harga yang kurang bersaing, kesiapan pasar dan kurang jelasnya peta produk impor sehingga positioning persaingan lebih jelas. Kondisi ini akan lebih berat dihadapi UMKM Indonesia pada saat diberlakukannya ASEAN Community yang direncanakan tahun 2015. Apabila kondisi ini dibiarkan, UMKM yang disebut mampu bertahan hidup dan tahan banting pada akhirnya akan bangkrut juga. Oleh karena itu, dalam upaya memperkuat UMKM sebagai fundamental ekonomi nasional, perlu kiranya diciptakan iklim investasi domestik yang kondusif dalam upaya penguatan pasar dalam negeri agar UMKM dapat menjadi penyangga (buffer) perekonomian nasional. 
INOBIS: Jurnal Inovasi Bisnis dan Manajemen Indonesia

Volume 2, Nomor 1, Desember 2018

Kristina Sedyastuti

Masalah lain yang dihadapi dan sekaligus menjadi kelemahan UMKM adalah kurangnya akses informasi, khususnya informasi pasar (Ishak, 2005). Hal tersebut menjadi kendala dalam hal memasarkan produk-produknya, karena dengan terbatasnya lakses informasi pasar yang mengakibatkan rendahnya orientasi pasar dan lemahnya daya saing di tingkat global. Miskinnya informasi mengenai pasar tersebut, menjadikan UMKM tidak dapat mengarahkan pengembangan usahanya secara jelas dan fokus, sehingga perkembangannya mengalami stagnasi. Kemampuan UMKM dalam menghadapi terpaan arus persaingan global memang perlu dipikirkan lebih lanjut agar tetap mampu bertahan demi kestabilan perekonomian Indonesia. Selain itu faktor sumber daya manusia di dalamnya juga memiliki andil tersendiri. Strategi pengembangan UMKM untuk tetap bertahan dapat dilakukan dengan peningkatan daya saing dan pengembangan sumber daya manusianya agar memiliki nilai dan mampu bertahan menghadapi pasar ACFTA, diantaranya melalui penyaluran perkreditan (KUR), penyediaan akses informasi pemasaran, pelatihan lembaga keuangan mikro melalui capacity building, dan pengembangan information technology (IT).

Demikian juga upaya-upaya lainnya dapat dilakukan melalui kampanye cinta produk dalam negeri serta memberikan untikan pendanaan pada lembaga keuangan mikro. Keuangan mikro telah menjadi suatu wacana global yang diyakini oleh banyak pihak menjadi metode untuk mengatasi kemiskinan (ref). Berbagai lembaga multilateral dan bilateral engembangkan keuangan mikro dalam berbagai program kerjasama. Pemerintah di beberapa negara berkembang juga telah mencoba mengembangkan keuangan mikro pada berbagai program pembangunan. Lembaga swadaya masyarakat juga tidak ketinggalan untuk turut berperan dalam aplikasi keuangan mikro (Prabowo dan Wardoyo, 2003). Pasar bebas ASEAN yang akan efektif diberlakukan pada tahun 2015 merupakan titik rawan perjuangan UMKM dan ekonomi kerakyatan. Berbagai kemudahan perdagangan antar negara seperti pembebasan bea impor dan kemudahan birokrasi akan mendorong meningkatnya impor komoditas ke negaranegara ASEAN. Iklim perdagangan tidak hanya akan didominasi oleh negara-negara ASEAN saja, akan tetapi juga perlu dipertimbangkan kehadiran China dengan produk-produknya yang memiliki daya saing tinggi dilihat dari harga dan kandungan teknologi. Oleh karena itu. dibutuhkan strategi yang tepat untuk meningkatkan daya saing dan sumber daya manusia khususnya untuk menghadapi pasar bebas ACFTA.

\section{Landasan Teori}

Dalam perekonomian Indonesia UMKM merupakan kelompok usaha yang memiliki jumlah paling besar dan terbukti tahan terhadap berbagai macam goncangan krisis ekonomi. Kriteria usaha yang termasuk dalam Usaha Mikro Kecil dan Menengah telah diatur dalam payung hukum. Berdasarkan Keputusan Menteri Keuangan Nomor 316/KMK.016/1994 tanggal 27 Juni 1994, usaha kecil didefinisikan sebagai perorangan. Kriteria Usaha Mikro Kecil dan Menengah (UMKM) :

a. Kriteria Usaha Mikro, Kecil Dan Mene ngah (UMKM) menurut UU Nomor 20 Tahun 2008 digolongkan berdasarkan jumlah aset dan omset yang dimiliki oleh sebuah usaha.

1 Usaha Mikro Maks. 50 Juta Maks. 300 Juta

2 Usaha Kecil > 50 Juta - 500 Juta > 300 Juta - 2,5 Miliar

3 Usaha Menengah > 500 Juta - 10 Miliar > 2,5 Miliar - 50 Miliar

( Sumber : Kementrian Koperasi dan Usaha Kecil dan Menengah, 2012 ) 
INOBIS: Jurnal Inovasi Bisnis dan Manajemen Indonesia

Volume 2, Nomor 1, Desember 2018

Kristina Sedyastuti

b. Kriteria Usaha Kecil Dan Menengah Berdasar Perkembangan, selain berdasar Undangundang tersebut, dari sudut pandang perkembangannya (Rahmana,2008) mengelompokkan UMKM dalam beberapa kriteria, yaitu:

1) Livelihood Activities, merupakan Usaha Kecil Menengah yang digunakan sebagai kesempatan kerja untuk mencari nafkah, yang lebih umum dikenal sebagai sektor informal. Contohnya adalah pedagang kaki lima.

2) Micro Enterprise, merupakan Usaha Kecil Menengah yang memiliki sifat pengrajin tetapi belum memiliki sifat kewirausahaan.

3) Small Dynamic Enterprise, merupakan Usaha Kecil Menengah yang telah memiliki jiwa kewirausahaan dan mampu menerima pekerjaan subkontrak dan ekspor

4) Fast Moving Enterprise, merupakam Usaha Kecil Menengah yang telah memiliki jiwa kewirausahaan dan akan melakukan transformasi menjadi Usaha Besar (UB).

\subsection{Pemberdayaan UMKM}

Dalam rangka pemberdayaan UMKM di Indonesia, (Bank Indonesia,2011) mengembangkan filosofi lima jari( Five finger philosophy), maksudnya setiap jari mempunyai peran masing-masing dan tidak dapat berdiri sendiri serta akan lebih kuat jika digunakan secara bersamaan.

1. Jari jempol, mewakili peran lembaga keuangan yang berperan dalam intermediasi keuangan, terutama untuk memberikan pinjaman/pembiayaan kepada nasabah mikro, kecil dan menengah serta sebagai Agents of development (agen pembangunan).

2. Jari telunjuk, mewakili regulator yakni Pemerintah dan Bank Indonesia yang berperan dalam Regulator sektor riil dan fiskal, Menerbitkan ijin-ijin usaha, Mensertifikasi tanah sehingga dapat digunakan oleh UMKM sebagai agunan, menciptakan iklim yang kondusif dan sebagai sumber pembiayaan.

3. Jari tengah, mewakili katalisator yang berperan dalam mendukung perbankan dan UMKM, termasuk Promoting Enterprise Access to Credit (PEAC) Units, perusahaan penjamin kredit Jari manis, mewakili fasilitator yang berperan dalam mendampingi UMKM, khususnya usaha mikro, membantu UMKM untuk memperoleh pembiayaan bank, membantu bank dalam hal monitoring kredit dan konsultasi pengembangan UMKM.

4. Jari kelingking, mewakili UMKM yang berperan dalam pelaku usaha, pembayar pajak dan pembukaan tenaga kerja.

Kebersamaan Usaha Mikro, Kecil, dan Menengah (UMKM) dan bank komersial merupakan salah satu dari sekian banyak bentuk simbiosis mutualisme dalam ekonomi.

Kebersamaan tersebut bukan saja bermanfaat bagi keduanya, tetapi juga bagi masyarakat dan pemerintah. Masyarakat menikmati ketersediaan lapangan kerja dan pemerintah menikmati kinerja ekonomi berupa naiknya Pendapatan Domestik Bruto (PDB), yang menyumbang lebih dari separuh PDB Indonesia. Namun demikian, kerja sama tersebut tetap perlu memegang prinsip kehati-hatian untuk memastikan terwujudnya manfaat bagi kedua pihak. 
INOBIS: Jurnal Inovasi Bisnis dan Manajemen Indonesia

Volume 2, Nomor 1, Desember 2018

Kristina Sedyastuti

\subsection{Pasar Bebas Asean dan ACFTA (Asean China Free Trade Area)}

Pasar bebas Asean akan diberlakukan pada tahun 2015. Hal ini menjadikan pemerintah Indonesia terus meningkatkan berbagai strategi untuk menghadapinya. Demikian juga, sejak disepakatinya perjanjian perdagangan bebas ASEAN-China (ACFTA) yang mulai diberlakukan pada 1 Januari 2010 mengharuskan pemerintah Indonesia. Pertama, apakah pemerintah Indonesia untuk melakukan sosialisasi terhadap publik mengenai kesepakatan ACFTA. Disamping itu pemerintah Indonesia diharapkan memiliki strategi besar untuk menghadapi ACFTA. Terkait dengan persepsi publik terhadap kesepakatan ACFTA. Sosialisasi penting untuk dijadikan sebagai bahan pertimbangan pemerintah Indonesia sebelum ACFTA diberlakukan. Dalam surveinya, LSI mengajukan beberapa pertanyaan terhadap publik menyangkut ACFTA. Dari hasil survei tersebut diketahui bahwa hanya sebagian kecil saja publik Indonesia yang mengetahui atau pernah mendengar kesepakatan/perjanjian perdagangan bebas ASEAN-China yang mulai berlaku pada 1 Januari 2010, terdapat 26,7 persen publik yang pernah mendengar mengenai kesepakatan perdagangan bebas ASEAN-China. Dari mereka yang pernah mendengar mengenai kesepakatan perdagangan bebas ASEAN-China, mayoritas publik (51,9 persen) mengatakan tidak setuju dengan kesepakatan perdagangan bebas. Ternyata temuan survei LSI tersebut menunjukkan bahwa publik cenderung mempersepsikan berlakunya ACFTA secara negatif. Publik menilai adanya perdagangan bebas ASEAN-China justru dapat membahayakan pasar dalam negeri dan ini jelas dapat merugikan neraca perdagangan Indonesia. Artinya China yang justru diuntungkan dengan adanya perdagangan bebas dan bukan Indonesia. Hal penting berikutnya terkait dengan kesiapan atau strategi besar pemerintah Indonesia menghadapi ACFTA.

\subsection{Peningkatan Daya Saing Produk Indonesia}

Menurut Organisation for Economic Co-operation and Development (OECD) menyebutkan bahwa daya saing adalah kemampuan perusahaan, industri, daerah, negara, atau antar daerah untuk menghasilkan faktor pendapatan dan faktor pekerjaan yang relatif tinggi dan berkesinambungan untuk menghadapi persaingan internasional. Oleh karena daya saing industri merupakan fenomena di tingkat mikro perusahaan, maka kebijakan pembangunan industri nasional didahului dengan mengkaji sektor industri secara utuh sebagai dasar pengukurannya. Sedangkan menurut Tambunan, 2001, tingkat daya saing suatu negara di kancah perdagangan internasional, pada dasarnya amat ditentukan oleh dua faktor, yaitu faktor keunggulan komparatif (comparative advantage) dan faktor keunggulan kompetitif (competitive advantage). Lebih lanjut, faktor keunggulan komparatif dapat dianggap sebagai faktor yang bersifat alamiah dan faktor keunggulan kompetitif dianggap sebagai faktor yang bersifat acquired atau dapat dikembangkan/diciptakan.

Selain dua faktor tersebut, tingkat daya saing suatu negara sesungguhnya juga dipengaruhi oleh apa yang disebut Sustainable Competitive Advantage (SCA) atau keunggulan daya saing berkelanjutan. Ini terutama dalam kerangka menghadapi tingkat persaingan global yang semakin lama menjadi sedemikian ketat/keras atau Hyper Competitive. Analisis Persaingan yang super ketat (Hyper Competitive Analysis) menurut D'Aveni dalam (Hamdy, 2001), merupakan analisis yang menunjukkan bahwa pada akhirnya setiap negara akan dipaksa memikirkan atau menemukan suatu strategi yang tepat, agar negara/perusahaan tersebut dapat tetap bertahan pada kondisi persaingan global yang sangat sulit. Menurut Hamdy Hadi, strategi yang tepat adalah strategi SCA (Sustained Competitive 
INOBIS: Jurnal Inovasi Bisnis dan Manajemen Indonesia

Volume 2, Nomor 1, Desember 2018

Kristina Sedyastuti

Advantage Strategy) atau strategi yang berintikan upaya perencanaan dan kegiatan operasional yang terpadu, yang mengkaitkan lingkungan eksternal dan internal demi pencapaian tujuan jangka pendek maupun jangka panjang, dengan disertai keberhasilan dalam mempertahankan/meningkatkan sustainable real income secara efektif dan efisien.

Menurut The Global Competitiveness Report, tahun 2011 peringkat daya saing Indonesia mengalami penurunan menjadi 46 dibanding tahun 2010 yang berada di posisi 44 . Hal ini menuntut perlunya dilakukan kaji ulang terhadap kebijakan, program dan kegiatan pembangunan yang dilakukan selama ini. Kementerian dan lembaga yang membidangi setiap pilar dan indikator yang mengalami penurunan peringkat perlu bekerja lebih dari biasa untuk menaikkan peringkat pada masing-masing indikator dan pilar daya saing tersebut. Selain itu, berbagai faktor umum yang menghambat peningkatan daya saing perlu dibenahi dengan cepat agar tahun berikutnya dan seterusnya peringkat daya saing Indonesia tidak merosot melainkan meningkat dengan konstan. Beberapa faktor yang mempengaruhi daya saing produk antara lain dipengaruhi beberapa faktor bisnis sebagaimana dalam Tabel 1 dibawah ini.

Tabel 1. Faktor-faktor Penghambat Daya Saing

\begin{tabular}{|l|l|l|}
\hline $\mathrm{N}$ & Faktor & Prosentase $(\%)$ \\
\hline 1 & KKorupsi & 15,4 \\
\hline 2 & Birokrasi pemerintah yang tidak efesien & 14.3 \\
\hline 3 & InInfrastruktur yang tidak memadai & 9.5 \\
\hline 4 & KKetidakstabilan politik & 7.4 \\
\hline 5 & AAkses pada pembiayaan & 7.2 \\
\hline 6 & Tenaga kerja terdidik yang memadai & 6.3 \\
\hline 7 & EEtika yang buruk & 6.2 \\
\hline 8 & KKetidakstabilan pemerintah & 6.1 \\
\hline 9 & InInflasi & 6.1 \\
\hline 10 & PPeraturan pajak & 6.0 \\
\hline 11 & TiTingkat pajak & 4.2 \\
\hline 12 & PPeraturan buruh yang membatasi & 3.6 \\
\hline 13 & KKriminalitas dan pencurian & 2.7 \\
\hline 14 & KKesehatan umum yang buruk & 2.5 \\
\hline 15 & PPeraturan mata uang asing & 2.3 \\
\hline
\end{tabular}

Sumber: World Economic Forum (WEF), 2011

Untuk meningkatkan daya saing dalam negeri maka 15 poin hambatan diatas secara serius harus mendapat tempat yang utama dalam kebijakan dan peraturan pemerintah yang mengacu pada pengurangan hambatan tersebut.

\subsection{Pentingnya Pemberdayaan UMKM}

Penduduk Indonesia yang berjumlah lebih dari 240 juta orang (menurut sensus 2010), ternyata hanya 0,24 persen adalah para wirausaha (interpreneur), atau hanya sekitar 400.000 orang yang berkecimpung dalam dunia usaha atau UMKM. Padahal agar perekonomian Indonesia dapat berkembang lebih cepat diperlukan lebih dari 2 persen dari jumlah penduduk sebagai wirausaha atau berkecimpung dalam UMKM. Singapura, sebuah negara kecil namun mempunyai 7 persen dari jumlah penduduknya merupakan wirausaha dan mempunyai banyak UMKM. Peran Pemerintah melalui Beberapa Program Pemberdayaan UMKM perkembangan 
INOBIS: Jurnal Inovasi Bisnis dan Manajemen Indonesia

Volume 2, Nomor 1, Desember 2018

Kristina Sedyastuti

Usaha Mikro, Kecil, dan Menengah (UMKM) di Indonesia tidak terlepas dari dukungan perbankan dalam penyaluran kredit kepada UMKM. Setiap tahun kredit kepada UMKM mengalami pertumbuhan dan secara umum pertumbuhannya lebih tinggi dibanding total kredit perbankan. Kredit UMKM adalah kredit kepada debitur usaha mikro, kecil dan menengah yang memenuhi definisi dan kriteria usaha mikro, kecil dan menengah sebagaimana diatur dalam UU No. 20 Tahun 2008 Tentang UMKM. Berdasarkan UU tersebut, UMKM adalah usaha produktif yang memenuhi kriteria usaha dengan batasan tertentu kekayaan bersih dan hasil penjualan tahunan. Keberhasilan Usaha Mikro, Kecil, dan Menengah (UMKM) di Indonesia juga tidak terlepas dari dukungan dan peran pemerintah dalam mendorong penyaluran kredit kepada UMKM.

Peran pemerintah dalam skim-skim kredit UMKM ini adalah pada sisi penyediaan dana APBN untuk subsidi bunga skim kredit dimaksud, sementara dana kredit/pembiayaan seluruhnya (100\%) berasal dari bank-bank yang ditunjuk pemerintah sebagai bank pelaksana. Selain itu pemerintah berperan dalam penyiapan UMKM agar dapat dibiayai dengan skim dimaksud, menetapkan kebijakan dan prioritas usaha yang akan menerima kredit, melakukan pembinaan dan pendampingan selama masa kredit, dan memfasilitasi hubungan antara UMKM dengan pihak lain. Pada dewasa ini skim kredit yang sangat familiar di masyarakat adalah Kredit Likuiditas Bank Indonesia (KLBI) sehingga peranan Bank Indonesia dalam pengembangan UMKM berubah menjadi tidak langsung. Pendekatan yang digunakan kepada UMKM bergeser dari development role menjadi promotional role. Pendekatan yang memberikan subsidi kredit dan bunga murah sudah bergeser kepada pendekatan yang lebih menitikberatkan pada kegiatan pelatihan kepada petugas bank, penelitian dan penyediaan informasi.Sabirin (2001) menjelaskan bahwa untuk memberdayakan masyarakat golongan ekonomi lemah atau sektor usaha kecil adalah dengan menyediakan sumber pembiayaan usaha yang terjangkau. Salah satu strategi pembiayaan bagi golongan ini adalah usaha kredit mikro. Lembaga keuangan mikro merupakan institusi yang menyediakan jasa-jasa keuangan penduduk yang berpendapatan rendah dan termasuk dalam kelompok miskin. Lembaga keuangan mikro ini bersifat spesifik karena mempertemukan permintaan dana penduduk miskin atas ketersediaan dana. Bagi lembaga keuangan formal perbankan, penduduk miskin akan tidak dapat terlayani karena Kesuksesan pemberdayaan UMKM akan terwujud bila semua stakeholder berperan secara bersama-sama sesuai peran masing-masing. Baik regulator termasuk Pemerintah Daerah, para pelaku UMKM dan dunia perbankan yang dapat bekerja sesauai dengan tugas dan fungsinya, maka keberhasilan dan kemajuan UMKM akan cepat terlaksana. Sehingga pada akhirnya peningkatan penerimaan pajak dari sisi penggalian wajib pajak baru maupun nilai pajaknya akan terus meningkat.

Pemerintah sebagai regulator, pada dasarnya telah banyak mengeluarkan program atau skim yang telah disediakan untuk memberdayakan UMKM.

Program ini hendaknya terus dioptimalisasikan. Program-program tersebuta antara lain:

Kredit Usaha Rakyat (KUR), Kredit Ketahanan Pangan dan Energi (KKPE), KKPE adalah kredit investasi atau modal kerja yang diberikan dalam rangka mendukung program ketahanan pangan, dan diberikan melalui kelompok tani atau koperasi. Program Usaha Agrobisnis Pertanian (PUAP)Usaha Rakyat (KUR), yang khusus diperuntukkan bagi UMKM dengan kategori usaha layak, namun tidak mempunyai agunan yang cukup dalam rangka persyaratan perbankan. KUR adalah Kredit atau pembiayaan kepada UMKM dan Koperasi yang tidak sedang menerima Kredit atau Pembiayaan dari Perbankan dan/atau yang tidak sedang menerima Kredit Program dari Pemerintah pada saat permohonan Kredit/Pembiayaan diajukan. Tujuan akhir diluncurkan Program KUR adalah meningkatkan perekonomian, pengentasan kemiskinan dan penyerapan tenaga kerja. KUR merupakan kredit yang diberikan 
INOBIS: Jurnal Inovasi Bisnis dan Manajemen Indonesia

Volume 2, Nomor 1, Desember 2018

Kristina Sedyastuti

oleh bank kepada UMKM dalam bentuk pemberian modal kerja dan investasi untuk usaha produktif yang feasible namun belum bankable. Tujuannya adalah tercapainya percepatan pengembangan sektor riil (terutama sektor pertanian, kehutanan, kelautan dan perikanan serta industri).

Kredit Usaha Pembibitan Sapi (KUPS), Program Nasional Pemberdayaan Masyarakat Mandiri (PNPM), Demikian juga program-program yang dikeluarkan oleh Badan Usaha Milik Negara (BUMN) dalam bentuk Program Kemitraan dan Bina Lingkungan (PKBL). Program ini berangkat dari kepedulian dari BUMN untuk memberdayakan UMKM melalui bagian laba sebesar 2,5 persen yang digunakan untuk pemberdayaan UMKM. Disisi lain Kementrian Koperasi dan UMKM dan Kementrian lainnya langsung melakukan pembinaan terhadap UMKM di seluruh wilayah tanah air. Termasuk Direktorat Jenderal Pajak Kementerian Keuangan langsung melakukan pembinaan dan pemberian fasilitas pajak kepada UMKM. Diharapkan juga pemberdayaan UMKM akan dilakukan oleh pihak swasta melalui Corporate Social Responsibility (CSR) yang mereka miliki, antara lain melalui bapak angkat, plasma, pembinaan manajemen dan berbagai kegiatan untuk pemasaran produk UMKM. CSR diharapkan juga digulirkan oleh industri perbankan Indonesia guna memberikan kemudahan dan akses kredit kepada para pelaku UMKM. Mengacu pada sasaran dan arah kebijakan pemberdayaan UMKM sebagaimana uraian di atas, maka diperlukan strategi pada tatanan makro, dan mikro melalui implementasi program-program pemberdayaan UMKM seperti sebagai berikut :

Insentif, Kebijakan, Pendapatan, Negara,Pembebasan bea masuk, PPN tidak dipungut/dibebaskan, Fasilitas PPh, Kebijakan Belanja, Negara, Subsidi Pajak Ditanggung Permerintah, Protektif

\subsection{Metode Penelitian}

Penelitian ini menggunakan pendekatan eksploratif deskriptif dengan menganalisis pemberdayaan UMKM dan meningkatkan daya saing dalam menghadapai pasar Global. Karya ilmiah ini juga dikembangkan dengan menggunakan pendekatan kajian literatur atau studi putaka. Pendekatan teori/konsep dilakukan dengan merujuk dari beberapa sumber, seperti buku, jurnal ilmiah, dan internet. Semua uraian gagasan yang ada digabungkan dalam satu susunan kerangka pemikiran.

\subsection{Hasil dan Pembahasan}

Penguatan lembaga pendamping melalui Peningkatan Capacity Building Setyobudi (2007) menyebutkan bahwa Bank Indonesia lebih fokus pada penguatan lembaga pendamping UMKM melalui peningkatan capacity building dalam bentuk pelatihan dan kegiatan penelitian yang menunjang pemberian kredit kepada UMKM. Beberapa upaya yang dilakukan antara lain:

a. pelatihan-pelatihan kepada lembaga pendamping UMKM, dalam rangka meningkatkan kemampuan kredit UMKM

b. Pendirian Pusat Pengembangan Pendamping UKM (P3UKM), sebagai pilot project. P3UKM antara lain bertugas melakukan pelatihan dan akreditasi pendamping UKM.

c. Pengembangan Sistem Informasi Terpadu Pengembangan Usaha Kecil (SIPUK) sebagai sarana untuk lebih menyebarluaskan secara cepat hasil-hasil penelitian dan berbagai informasi lainnya. SIPUK terdiri dari Sistem Informasi Baseline Economic Survey (SIB), 
INOBIS: Jurnal Inovasi Bisnis dan Manajemen Indonesia

Volume 2, Nomor 1, Desember 2018

Kristina Sedyastuti

Sistem Informasi Agroindustri Berorientasi Ekspor (SIABE), Sistem Informasi Pola Pembiayaan/ lending model Usaha Kecil (SILMUK), Sistem Penunjang Keputusan Untuk Investasi (SPKUI); dan Sistem Informasi Prosedur Memperoleh Kredit (SIPMK). SIPUK ini dapat diakses melalui website Bank Indonesia.

d. Berbagai penelitian dalam rangka memberikan informasi untuk mendukung pengembangan UMKM. Kegiatan penelitian terutama diarahkan untuk mendukung penetapan arah dan kebijakan Bank Indonesia dalam rangka pemberian bantuan teknis dan juga dalam rangka penyediaan informasi yang berguna dalam rangka pengembangan UMKM. Penelitian tersebut disesuaikan dengan kebutuhan pengembangan UMKM serta untuk menggali potensi sektor UMKM di tiap-tiap daerah di Indonesia. Dalam upaya meningkatkan peran UMKM untuk mendorong pertumbuhan ekonomi. Bank Indonesia melakukan kajian identifikasi peraturan pusat dan daerah dalam rangka pengembangan UMKM serta kajian dan implementasi pilot project klaster pengembangan UMKM.

\subsection{Strategi Pengembangan Sumber Daya Manusia pada UMKM melalui IT (Information Technology)}

Teknologi informasi merupakan bentuk teknologi yang digunakan untuk menciptakan, menyimpan, mengubah, dan menggunakan informasi dalam segala bentuknya. Melalui pemanfaatan teknologi informasi ini, perusahaan mikro, kecil maupun menengah dapat memasuki pasar global. Perusahaan yang awalnya kecil seperti toko buku Amazon, portal Yahoo, dan perusahaan lelang sederhana Ebay, ketiganya saat ini menjadi perusahaan raksasa hanya dalam waktu singkat karena memanfaatkan teknologi informasi dalam mengembangkan usahanya. Pemanfaatan teknologi informasi dalam menjalankan bisnis atau sering dikenal dengan istilah e-commerce bagi perusahaan kecil dapat memberikan fleksibilitas dalam produksi, memungkinkan pengiriman ke pelanggan secara lebih cepat untuk produk perangkat lunak, mengirimkan dan menerima penawaran secara cepat dan hemat, serta mendukung transaksi cepat tanpa kertas. Pemanfaatan internet memungkinkan UMKM melakukan pemasaran dengan tujuan pasar global, sehingga peluang menembus ekspor terbuka luas. Disamping itu biaya transaksi juga bisa diturunkan. Biaya transaksi (Transaction Cost), merupakan biaya-biaya yang timbul dari proses kegiatan bisnis. Biaya ini mencakup biaya komunikasi (baik di dalam organisasi dan layanan, sesuai dengan kontrak dan banyak lagi. Biaya dari semua ini berpotensi dapat dikurangi dengan sistem TI yang lebih baik.

Hal ini terutama berlaku dengan jaringan, yang dapat mengurangi biaya komunikasi antara bagian geografis terpisah dari organisasi, pemasok dan pelanggan. Hal positif yang dapat diperoleh dengan memanfaatkan jaringan internet dalam mengembangkan usaha adalah:

(1) dapat mempertinggi promosi produk dan layanan melalui kontak langsung, kaya informasi, dan interaktif dengan pelanggan,

(2) menciptakan satu saluran distribusi bagi produk yang ada,

(3) biaya pengiriman informasi ke pelanggan lebih hemat jika dibandingkan dengan paket atau jasa pos,

(4) waktu yang dibutuhkan untuk menerima atau mengirim informasi sangat singkat, hanya dalam hitungan menit atau bahkan detik.

Mengapa perlu dibuat Pusat Pengembangan UMKM Berbasis IT di tingkat kabupaten atau kecamatan. Hal ini didasari pada kenyataan bahwa sebagian besar UMKM berlokasi di 
INOBIS: Jurnal Inovasi Bisnis dan Manajemen Indonesia

Volume 2, Nomor 1, Desember 2018

Kristina Sedyastuti

desa-desa dan kota-kota kecamatan, serta belum mampu untuk memiliki jaringan internet sendiri, apalagi memiliki websitenya. Padahal untuk pengembangan usaha dengan akses pasar global harus memanfaatkan media virtual. Pusat Pengembangan UMKM Berbasis IT ini akan memudahkan UMKM dalam memperluas pasar baik di dalam negeri maupun pasar luar negeri dengan waktu dan biaya yang efisien. Sehingga tingkat kesejahteraan masyarakat UMKM dan tenaga kerja yang terlibat di dalamnya akan meningkat, dan secara bersinergi akan berdampak positif terhadap keberhasilan pembangunan nasional. Pada dasarnya produk UKM Indonesia banyak memiliki kualitas sama dengan produk luar negeri, atau bahkan lebih baik lagi. Namun produk luar tersebut seringkali unggul dalam teknologi, baik dalam teknologi produksi, pengemasan maupun pemasarannya. Guna memenangkan persaingan, UMKM juga harus berkembang sesuai dengan perkembangan jaman. Pada dasarnya dengan bantuan Teknologi Informasi dan Komunikasi dapat meningkatkan kinerja sehingga lebih efektif dan efisien. Jadi meskipun ada sedikit perbedaan cost dengan sistem tradisional, UMKM dapat menikmati fasilitas dari IT yang akan memberikan return yang sepadan. Dengan IT UMKM akan lebih siap untuk bersaing tidak hanya di dalam negeri tetapi juga dengan produk-produk luar negeri. Kita dapat bersaing dari segi kualitas, pengemasan, dan kecepatan operasi perusahaan serta yang lebih penting lagi adalah dalam pemasaran produk UMKM

\section{Simpulan}

Dari hasil analisis diatas maka strategi untuk mengembangkan Usaha Mikro, Kecil, dan Menengah (UMKM) di Indonesia tidak terlepas dari dukungan perbankan dalam penyaluran kredit. Saat ini skim kredit yang sangat familiar di masyarakat adalah Kredit Usaha Rakyat (KUR), yang khusus diperuntukkan bagi UMKM dengan kategori usaha layak, tanpa agunan. Selain itu penguatan lembaga pendamping UMKM dapat dilakukan melalui kemudahan akses serta peningkatan capacity building dalam bentuk pelatihan dan kegiatan penelitian yang menunjang pemberian kredit kepada UMKM. Strategi untuk mengantisipasi mekanisme pasar yang makin terbuka dan kompetitif khususnya di kawasan Asean adalah penguasaan pasar, yang merupakan prasyarat untuk meningkatkan daya saing UMKM. Agar dapat menguasai pasar, maka UMKM perlu mendapatkan informasi dengan mudah dan cepat, baik informasi mengenai pasar produksi maupun pasar faktor produksi untuk memperluas jaringan pemasaran produk yang dihasilkan oleh UMKM. Aplikasi teknologi informasi pada usaha mikro, kecil dan menengah akan mempermudah UMKM dalam memperluas pasar baik di dalam negeri maupun pasar luar negeri dengan efisien. Pembentukan Pusat Pengembangan UMKM berbasis IT dianggap mampu mendorong pertumbuhan dan perkembangan usaha mikro, kecil, dan menengah di era teknologi informasi saat ini.

Untuk meningkatkan daya saing diperlukan sinergi antara peran pemerntah selaku pembuat kebijakan serta lembaga pendamping, khususnya lembaga keuangan mikro untuk mempermudah akses perkreditan dan perluasan jaringan informasi pemasaran. Selain itu, budaya mencintai produksi dalam negeri juga perlu dipupuk agar UMKM berkembang dan perekonomian nasional menjadi lebih kuat. Pelaku usaha mikro, kecil dan menengah perlu aktif untuk bekerjasama dan berkoordinasi dengan Pemerintah maupun Pemerintah Daerah untuk terus melakukan pembinaan dan pelatihan melalui peningkatan capacity building dan penerapan aplikasi information technology (IT), termasuk mengefektifkan kembali web Pemda-Pemda saat ini yang tidak optimal sebagai basis komunikasi UMKM di daerah. 
INOBIS: Jurnal Inovasi Bisnis dan Manajemen Indonesia

Volume 2, Nomor 1, Desember 2018

Kristina Sedyastuti

\section{Daftar Referensi}

Bank Indonesia. 2011. Five Finger Philosophy:Upaya Memberdayakan UMKM,(online),(http://www.bi.go.id/web/id/UMKMBI/Koordinasi/Filosofi+Lima+Jari /,diakses 3 oktober 2011)

BPS.2011.Produk Domestik Bruto.(online),(http://www.bps.go.id/index.php?news=730, diakses 12 oktober 2011)

Brown, Lisanne, Anne LaFond, and Kate Macintyre. 2001. Measuring Capacity Building, Carolina Population Center, Chapel Hill : University of North Carolina,

Campobasso, L and D Davis, 2001. Reflection on Capacity Building, the California Wellness Foundation Journal, Volume 2 no. 2. California : Wellness Foundation

Galeri UKM. 2011. Kriteria Usaha Mikro Kecil dan Menengah, (Online), (http://galeriukm.web.id/news/kriteria-usaha-mikro-kecil-dan-menengah-umkm, diakses 1 oktober 2011)

Ishak, Effendi. 2005. Artikel : Peranan Informasi Bagi Kemajuan UKM. Yogyakarta : Kedaulatan Rakyat.

Loudon, Kenneth C dan Loudon, Jane P. 2007. Management Information System : Managing the Digital Firm. Jakarta : Pearcon Education

Prabowo, Hendro dan Wardoyo. 2003. Kinerja Lembaga Keuangan Mikro bagi Upaya Penguatan Usaha Mikro, Kecil, dan Menengah di Wilayah Jabotabek. Depok : Universitas Gunadarma

Rahmana, Arief. 2008. Usaha Kecil dan Menengah (UKM), Informasi Terdepan tentang Usaha Kecil Menengah,(online), http://infoukm.wordpress.com, diakses 1 oktober 2011)

Republik Indonesia. 2008. Undang-Undang No. 20 Tahun 2008 tentang Usaha Mikro, Kecil, dan Menengah. Jakarta : Sekretariat Negara

Sabirin, S. 2001. Pemanfaatan Kredit Mikro untuk Mendorong Pertumbuhan Ekonomi Rakyat di dalam Era Otonomi Daerah. Orasi Ilmiah Lustrum IX Universitas Andalas, Padang, 13 September 2001.

Scot, W.R. 1997. Financial Accounting Theory. New Jersey : Prentice-Hall

Setyobudi, Andang. 2007. Peran serta Bank Indonesia dalam Pengembangan Usaha Mikro, Kecil, dan Menengah (UMKM), Buletin Hukum Perbankan dan Kebanksentralan, Volume 5, nomor 2, Agustus 2007. Jakarta: Bank Indonesia

Sudaryanto. 2011. The Need for ICT-Education for Manager or Agribusinessman to Increasing Farm Income : Study of Factor Influences on Computer Adoption in East Java Farm Agribusiness. International Journal of Education and Development, JEDICT, Vol 7 No 1 halm. 56-67

Sudaryanto dan Hanim,Anifatul. 2002. Evaluasi kesiapan UKM Menyongsong Pasar Bebas Asean (AFTA) : Analisis Perspektif dan Tinjauan Teoritis. Jurnal Ekonomi Akuntansi dan Manajemen, Vol 1 No 2, Desember 2002

Suyanto, M. 2005. Artikel, Aplikasi IT untuk UKM Menghadapi Persaingan Global. Yogyakarta

Tambunan, Tulus, 2010, Center for Industry, SME and Business Competition Studies, Trisakti University, Indonesia 